\title{
Politics, Islam, Islamic Trade Law, Nationalism: Titik Singgung Kompetensi Peradilan Umum (Perdata) dan Peradilan Tata Usaha Negara Secara Kompetensi Absolut (Absolute Competency)
}

\author{
Rizaldy Pedju \\ Institut Agama Islam Negeri(IAIN) Manado \\ Rizaldy.pedju@iain-manado.ac.id
}

\begin{abstract}
General Courts (Civil) and State Administrative Courts (TUN) are part of State institutions that are legitimately authorized to examine, adjudicate, decide, and resolve any disputes put forward to them. Competence of practical and theoretical Courts, divided into two , namely absolute authority (relative competency) and relative authority (relative juricdiction). However, relative authority does not become a discussion in this section. The intersection of competencies / authority between General (Civil) and State Administrative Courts (TUN) is very likely to occur, for example in the case of unlawful acts by the ruler (Onrechtamtigedaad van ambtsdrager). This offense is due to the nature of unlawful acts by two-sided rulers, that is, it can act against the law based on a civil law relationship or based on a public relationship. This paper, will conduct a theoretical study of how the tangent point between competency / authority of General Courts (Civil) and the State Administrative Court (TUN) by Absolute Competency. This paper uses the library research approach with the analysis of legislation analysis in force in Indonesia to find substance in terms of answering the problem formulation in this study.
\end{abstract}

Keywords: Tangent Point, Competence, General Justice, State Administrative Courts, Absolute Competence.

Abstrak. Peradilan Umum (Perdata) dan Peradilan Tata Usaha Negara (TUN) merupakan bagian dari institusi Negara yang resmi sah (legitimed) diberi kewenangan dalam memeriksa, mengadili, memutus, serta menyelesaikan setiap sengketa yang diajukan padanya.Kompetensi Peradilan praksis maupun teoritis, dibagi menjadi dua, yaitu kewenangan absolut (absolute competency) dan kewenangan relatif (relative juricdiction) Namun demikian, kewenangan relatif tidak menjadi bahasan dalam bagian ini.Persinggungan kompetensi/kewenangan antara Peradilan Umum (Perdata) dengan Peradilan Tata Usaha Negara (TUN) sangat mungkin terjadi, misalnya dalam hal perbuatan melawan hukum oleh penguasa (Onrechtamtigedaad van ambtsdrager).Persinggungan ini dikarenakan sifat dari perbuatan melawan hukum oleh penguasa bersegi dua, yaitu dapat bersegi perbuatan melawan hukum berdasar suatu hubungan hukum keperdataan atau berdasarkan suatu hubungan publik. Tulisan ini, akan melakukan kajian teoritik tentang bagaimana titik singgung antara kompetensi/kewenangan Peradilan Umum (Perdata) dengan Peradilan Tata Usaha Negara (TUN) Secara Kompetensi Absolut (Absolute Competency). Tulisan ini menggunakan pendekatan library research dengan studi analisa peraturan perundangundangan yang berlaku di Indonesia guna menemukan substansi dalam hal untuk menjawab rumusan masalah dalam penelitian ini.

Keywords: Titik Singgung, Kompetensi, Peradilan Umum, Peradilan Tata Usaha Negara, Kompetensi Absolut. 


\section{Pendahuluan}

Peradilan umum merupakan peradilan resmi Negara yang memiliki kompetensi atau kewenangan yang bersifat umum, menyangkut ranah pidana dan perdata umum.Di dalam badan peradilan umum terdapat peradilan khusus seperti Peradilan Niaga, Peradilan Hubungan Industrial, Peradilan tipikor dan Peradilan HAM. ${ }^{1}$ Namun yang menjadi sorotan dalam tulisan ini adalah kompetensi peradilan umum (perdata) secara absolut, sehingga ranah peradilan khusus tidak masuk dalam ranah pembahasan.

Sedangkan Peradilan Tata Usaha Negara (TUN) lebih mudah keberadaannya karena ruang lingkup kompetensi lebih kecil dibandingkan peradilan umum, karena objek Peradilan Tata Usaha Negara (TUN) adalah Keputusan Tata Usaha Negara (beschikking) yang diterbitkan oleh Badan/Pejabat TUN.

Menyangkut pemahaman kompetensi suatu peradilan di Indonesia secara umum dibagi atas dua yaitu, kompetensi absolut dan kompetensi relatif.K ompetensi/ Kewenangan absolut (absolute competency) yang selanjutnya disebut dengan competency didefinisikan sebagai "The right incourt to exercise jurisdiction in a particular case"2atau kewenangan sesuatu badan pengadilan untuk mengadili perkara tertentu.Sedangkan kompetensi relatif adalah kewenangan memeriksa, mengadili atau memutuskan perkara berdasarkan pembagian daerah hukum, dalam hal ini diterapkan asas Actor sequitor forum rei, artinya yang berwenang mengadili adalah pengadilan negeri tempat tinggal tergugat

1 M. Natsir Asnawi, Hukum Acara Perdata (Teori Praktik dan Permasalahannya di Peradilan Umum dan Peradilan Agama), (Yogyakarta: UII Press, 2016), h. 45

${ }^{2}$ Henry Cembell Black, Black's Law Dictionary (Revised Fourth Edition), (Minnesota: West Publishin, 1968), h. 355
(Pasal 118 ayat (1) H.I.R). Ranah kompetensi absolut menjadi titik fokus penulisan ini, untuk itu dalam menganalisa kompetensi absolut terhadap dua peradilan ini, ada dua hal yang secara bersamaan terkandung dalam pemahaman dan implementasi kewenangan absolut terhadap badan suatu peradilan, yaitu :

1) Kewenangan badan peradilan dalam memeriksa, mengadili, memutus, dan menyelesaikan perkara-perkara tertentu (specified matters);

2) Pada saat bersamaan, perkaraperkara dimaksud mutlak tidak dapat diadili oleh badan peradilan dalam lingkup peradilan lainnya.

Kewenangan mengadili secara normatif dibagi menjadi dua, yaitu kekuasaan kehakiman atribusi (atributie van rechtsmacht) dan kekuasaan kehakiman distribusi (distributie van rechtsmacht). Atribusi kekuasaan kehakiman adalah kewenangan mutlak kompetensi absolut suatu pengadilan; kewenangan badan pengadilan didalam memeriksa perkara tertentu dan secara mutlak tidak dapat diperiksa oleh badan pengadilan lain. ${ }^{3}$ Sementara itu, distribusi kewenangan mengadili merupakan kewenangan mengadili suatu pengadilan berdasarkan daerah hukum tertentu. ${ }^{4}$ Selain dua jenis pembedaan kewenangan mengadili tersebut, Yahya Harahap menambahkan satu jenis pembagian kekuasaan lainnya, yaitu kewenangan mengadili berdasarkan faktor kewenangan khusus (specified jurisdiction) yang diberikan undangundang kepada badan extra judicial seperti Arbitrase atau Mahkamah Pelayaran. ${ }^{5}$

\section{3ibid}

${ }^{4}$ M. Yahya Harahap, Hukuum Acara Perdata: Tentang Gugatan, Persidangan Pentitaan Pemukuan dan Pengadilan(Jakarta: Sinar Grafika, 2007), h. 179-180.

5ibid 
Kewenangan absolut tiap-tiap lingkungan pengadilan sebenarnya sudah ditentukan secara terperinci dalam perundang-undangan Peradilan Umum misalnya, kewenangannya diatur dalam Undang-Undang Nomor 2 Tahum 1986 tentang Peradilan Umum yang telah diubah dengan Undang-Undang Nomor 8 Tahun 2004 dan Undang-Undang Nomor 49 Tahun 2009. Sementara itu, kewenangan absolut Peradilan Agama diatur dalma Undang-Undang Nomor 7 Tahun 1998 tentang Peradilan Agama yeng telah diubah dengan Undang-Undang Nomor 3 Tahun 2006 dan Undang-Undang Nomor 50 Tahun 2009. Adapun Peradilan Tata Usaha Negara (PTUN), kewenangannya diatur dalam UndangUndang Nomor 5 Tahun 1986 yang telah diubah dengan Undang-Undang Nomor 9 Tahun 2004 dan Undang-Undang Nomor 51 Tahun 2009.

Namun demikian, dalam praktiknya eksplansi kewenangan absolut pada tiaptiap pengadilan pada undang-undang tersebut masih menibulkan permasalahan di lapangan.Sifat bahasa perundangundangan yang sebagian masih terlalu umum menyebabkan peluang munculnya penafsiran beragama kian signifikan.Tidak jarang, bahkan dalam keadaan tertentu, para Hakim harus mengambil suatu tindakan diskresioner untuk memutuskan apakah perkara tersebut merupakam kewenangan peradilan tertentu atau menjadi kewenangan peradilan lainnya.

Sifat bahasa undang-undang yang demikian pada dasarnya tidaklah salah karena dalam konsep legal drafting, bahasa undang-undang lebih diarahkan pada bahsa yang general alias tidak terlalu teknis sehingga inklusif. ${ }^{6}$ Pemecahan atas

${ }^{6}$ Sifat inklusif dalam bahasa undangundang yang general bertujuan agar dapat mencakup berbagai hal dalam kenyataan di masyarakat maupun dalam dinamika peradilan. Ketercakuoan tersebut hanya dapat dicapai melalui kontruksi bahasa undang-undang yang lebih umum. Sifat teknis nantinya dapat dijabarkan kemungkinan beragamnnya penafsiran sebenarnya dapat dilakukan melalui bagian penjelasan umum dan penjelasan pun terkadang terlalu sederhana dan tidak memberi petunjuk yang cukup rinci guna menentukan demarkasi yang jelas kewenangan pengadilan tertentu.

Permasalahan kewenangan tiap-tiap lingkungan peradilan menjadi sedemikian urgen karena bila suatu perkara diadili di pengadilan tertentu sementara objek perkaranya (objectum litis) bukan menjadi kewenangan pengadilan tersebut maka putusan terhadapnya batal demi hukum atau setidak-tidaknya dapat dibatalkan. Perintah undang-undang untuk memperhatikan betul batasan kewenanganpengadilan bersifat imperatif, sehingga pengadilan wajib menyatakan diri tidak berwewenang bila Majelis Hakim yang mengadili menilai bahwa objekctum litis perkara in konkreto merupakan kewenangan atau domain dari lingkungan pengadilan lainnya. Hal ini secara tegas dinyatakan dalam pasal 134 HIR/160 R. BG:

"jika perselisihan itu adalah suatu perkara yang tidak masuk wewenang pengadilan negeri, maka pada setiap waktu dalam pemeriksaan perkara itu, dapat diminta supaya hakim menyatakan dirinya tidak berwenang dan hakim wajib mengakuinya karena jabatannya"7

Dari redaksi pasal tersebut, dapat dipahami bahwa menilai apakah objectum litis merupakan kewenangan absolut suatu pengadilan adalah kewajiban Hakim (Majelis Hakim). Tanpa ada ekspresi sekalipun, Hakim karena jabatnnya (ex officio) wajib menyatakan diri tidak berwewenang bila nyata-nyata objectum litis perkara tersebut bukan menjadi kewenangan pengadilan-nya, melainkan

antar lain melalui bagian penjelasan umum mauoun diterbitkannya peraturan pemerintah sebagai pelaksanaan dari undang-undang tersebut.

${ }^{7}$ Riduan Syahrani, Himpunan Peraturan Hukum Acara Perdata Indonesia (Bandung: Alumni, 1991), h.201 
menjadi kewenangan pengadilan dalam lingkungan peradilan lain. Alih-alih melanjutkan pemeriksaan pokok perkara, Hakim, sesaat setelah menyadari hal tersebut wajib segera menjatuhkan putusan yang menyatakan dirinya tidak berwenang.

Pada tataran praktis, masalah persinggungan kewenangan antar pengadilan tidak sesederhana yang dipahami selama ini. Masalah persinggungan kewenangan bukan permaslahan batasan kewenangan an sich semata, namun dalam praktinya persinggungan kewenangan juga merupakan masalah interprestasi atas makna dari bahasa undang-undang. Perbedaan interpretasi di kalangan Hakim perihal batasana kewanangan tiap-tiap lingkungan keputusan atas hal demikian. Boleh jadi misalnya, satu Hakim memandang suatu perkaraa merupakan kewenangan Pengadilan Negeri, namun Hakim lain memandang perkara tersebut menjadi kewenangan Pengadilan Agama, juga sebaliknya.

$\begin{array}{llr}\text { Yahya Harahap mengemukakan } \\ \text { bahwa salah satu hal mengapa } \\ \text { pembahasan } & \text { mengenai r batasan }\end{array}$
kewenangan masing-masing lingkungan pengadilan adalah agar pengajuan atau penyampaian suatu perkara (gugatan/permohonan) ke suatu pengadilan tidak keliru.Kekeluruan dalam mengajukan gugatan/permohonan menyebabkan gugatan/permohonan dimaksud dapat dinyatakan tidak dapat diterima (niet onvankelijke verklard) dengan dasar bahwa pengadilan tersebut tidak berwenang mengadilinya. ${ }^{8}$ Lebih lanjut, hemat penulis, kekeliruan dalam mengajukan gugatan/permohonan ke suatu pengadilan (meskipun diputus Kabul/tolak) mengurangi legitimasi putusan tersebut, karena sangat terbuka kemungkinan pengadilan yang memutus tidak berwenang.Hal ini sangat mungkin persinggungan sehingga bila tidak cermat meneliti pengadilan mana yang sekiranya lebi berwewenang maka putusan terhadapanya (putusan yang bersifat positif) dapat berkurang legitimasinya, bahkan sampai pada tahap tertentu putusan dapat batal demi hukum (mull and void) atau setidak-tidaknya dapat dibatalkan.

Karena itu, penting kiranya membahas permasalahan titik singgung kewenangan mengadili dari berbagai perspektif.Demikian, sehingga nantinya diperoleh suatu gambaran utuh mengenai bagaimana seharusnya.Hakim dalam menilai titik singgung kewenangan hingga mengambil suatu konklusi apakah objectum litis-nya menjadi kewenangn suatu pengadilan dan bukan menjadi kewenangan pengadilan lainnya.

Dalam uraian diatas, maka penulis dapat merumuskan masalah dalam penelitian ini yaitu: Bagaimana Titik Singgung Kompetensi Peradilan Umum (Perdata) dan Peradilan Tata Usaha Negara Secara Kompetensi Absolut (Absolute Competency).

\section{Kompetensi Absolut Peradilan Umum (Perdata)}

Kewenangan absolut Peradilan Umum diatur dalam beberapa perundangundangan. Pengadilan negeri sebagai salah satu bagian atau kamar (chamber) dalam Peradilan Umum memiliki kewenangan absolut sebagaimana tercantum dalam Undang-Undang Nomor 2 Tahun 1986 tentang Peradilan Umum dalam pasal 50 tersebut dikemukakan bahwa kewenangan absolut (absolute competency) Pengadilan Negeri yaitu :

"Pengadilan Negeri bertugas dan berwenang memeriksa, memutus dan menyelesaikan perkara pidana dan perkara perdata ditingkat pertama." 9

Rumusan dalam pasal tersebut masih bersifat sangat umum (Fully 
General) sehingga apa yang dimaksud dengan "perdata umum" sebagai kewenangan absolut pengadilan negeri perlu dijabarkan lebih lanjut. Perdata umum dalam pemahaman an sich merupakan segala jenis perkara atau sengketa yang masuk dalam ranah umum. Sengketa dapat terjadi antara individu dengan individu, individu dengan badan hukum/organisasi pemerintah dan non pemerintah/kelompok masyarakat, kelompok masyarakat dengan badan hukum/organisasi pemerintah dan non pemerintah/kelompok masyarakat lainnya.

Bila memperhatikan literaturliteratur hukum perdata, hukum acara perdata serta berbagai ketentuan dalam kitab undang-undang hukum perdata, maka perdata umum mencangkup paling tidak tiga hal, yaitu :

a) Orang (Person)

Orang merupakan subjek hukum yang memiliki atribut hak dan kewajiban berdasarkan hukum.Orang dalam hukum perdata mencakup orang/manusia (natuurlijke person) dan badan hukum (rechts person).Perkara atau sengketa perdata berkenaan dengan orang pada dasarnya mencakup dua hal yaitu keadaan hukum (recht hoedanigheid) dan kewenangan hukum (recht hevoegheid).

Sengketa mengenai orang dalam lapangan hukum perdata sangat variatif.Konfigurasi mengenai "orang" dalam lapangan hukum perdata membentang dari sifat dan eksistensi orang secara individual hingga sifat dan eksistensi dalam hubungannya dengan orang atau dunia diluar dirinya. Mengenai bentuk sengketa atau perkara yang berkaitan dengan orang, dapat dilihat dari berbagai ketentuan mengenai orang hukum diantaranya sebagai berikut ${ }^{10}$;

1) Permohonan perubahan nama yang diajukan oleh pihak yang

${ }^{10}$ Lihat Mahkamah Agung RI, Pedoman Pelaksanaan Tugas dan Administrasi pengadilan dalam Empat Lingkungan Peradilan, 2007, h. 45-57 menghendaki perubahan nama atau identitas diakrenakan berbagai hal, misalnya adanya perbedaan nama pada berbagai identitas maupun aktaakta sehubungan denga dirinya maupun untuk kepentingan lainnya,

2) Permohonan pengangkatan wali bagi anak yang belum dewasa 9belum mencapai umur 18 tahun) dan tidak berada dalam kekuasaan orang tua anaknya sebagaimana diatur dalam kekuasaan orang tua anaknya sebagaiman diatur dalam UndangUndang Nomor 1 Tahun 1974 tentang perkawinan pasal 50-54. Selain pengangkatan anak dalam ketentuan tersebut juga mencakup pencabutan kekuasaan wali bagi anak dan perpindahan perwalian.

3) Permohonan pewarganegaraan (naturalisasi) sebagaiman diatur dalam Undang-Undang Nomor 12 Tahun 2006 tentang Kewarganegaraan Republik Indonesia.

4) Permohonan izin kawin (UndangUndang Nomor 1 Tahun 1974 tentang perkawinan Pasal 6 ayat (5)

5) Permohonan atau gugatan pembatalan dan atau pencegahan perkawinan

6) Gugatan tentang ahli waris

\section{b) Benda (zaaken)}

Terkait dengan benda (zaaken), kewenangan pengadilan negeri mencakup segala hal yang berkaitan dengan benda baik berwujud maupun tidak berwujud. Dalam lapangan hukum keluarga, sengketa kebendaan yang menjadi kewenangan pengadilan negeri adalah gugatan harta bersama dan gugatan harta waris bagi mereka yang beragama selain islam. Di luar itu, pengadilan negeri berwenang untuk mengadili tentang sengketa pertanahann dengan berbagai atribut hak yang melekat di dalamnya, diantaranya hak milik, hak gunna usaha, hak guna bangunan, hak pakai, hak sewa. 
Pengadilan Negeri juga berwenang mengadili sengketa milik atas benda selain tanah baik itu benda yang sifatnya memberikan kepuasan (zakelijk genotsrecht) maupun benda yang sifatnya memberikan jaminan (zakelijk zakerheidsrecht).

\section{c) Perjanjian (verbintenis)}

Perjanjian (verbintenis) adalah hubungan hukum kekayaan harta benda (vermoegenrecht) antara dua orang atau lebih yang memberi kekuatan hak (recht) pada satu pihak (schuldeiser) untuk memperoleh prestasi (plich) dan sekaligus mewajibkan pada pihak lain untuk menunaikan prestasi (schuldenaar) ${ }^{11}$.Dalam perjanjian melekat unsur perikatan (overenkomst). Bentuk sengketa yang pada umumnya terjadi dalam lapangan hukum perjanjian antara lain cidera janji (wanprestasi), perbuatan melawan hukum (onrechtmatigedaad, pembayaran yang tidak diwajibkan (onverschuldigde betaling), sengketamengenai kontrak baku, klausul eksonerasi, perlindungan konsumen, dan sebagainya. Bentuk-bentuk sengketa dimaksud merupakan kewenangan absolut dari Pengadilan Negeri.

\section{Kompetensi Absolut Peradilan Tata Usaha Negara}

Keberadaan Peradilan Tata Usaha Negara dimulai dari lahirnya UndangUndang Nomor 5 Tahun 1986 tentang Peradilan Tata Usaha Negara sebagaimana telah diubah dengan Undang-Undang Nomor 9 Tahun 2004 dan Undang-Undang Nomor 51 tahun 2009 serta mulai beroperasi pertama kali pada tanggal 14 januari 1991 dengan diterbitkan PP No. 7 Tahun 1991 tentang penerapan UndangUndang Nomor 5 Tahun 1986 tentang Peradilan Tata Usaha Negara. Dalam pasal 47 Undang-Undang Nomor 5 Tahun 1986

\footnotetext{
${ }^{11}$ M. Yahya Harahap, Segi-Segi Hukum Perjanjian(Bandung: Alumni, 1986), h. 6
}

tentang Peradilan Tata Usaha Negara sebagaimana telah diubah dengan Undang-Undang Nomor 9 Tahun 2004 dan Undang-Undang Nomor 51 Tahun 2009 telah diatur tentang Kompetensi Peradilan Tata Usaha Negara dalam sistem peradilan di Indonesia yaitu bertugas dan berwenang dalam memeriksa, memutus dan mengadili serta menyelesaikan sengketa tata usaha Negara.

Kompetensi absolut suatu badan pengadilan adalah kewenangan yang berkaitan untuk mengadili suatu perkara menurut objek atau materi atau pokok sengketa.Adapun yang menjadi objek sengketa di Pengadilan Tata Usaha Negara adalah Keputusan Tata Usaha Negara (beschikking) yang diterbitkan oleh Badan/Pejabat TUN. Sebagaimana disebutkan dalam pasal 1 angka 9 Undang-Undang Nomor 51 Tahun 2009 tentang perubahan kedua Undang-Undang Nomor 5 Tahun 1986 tentang Peradilan Tata Usaha Negara. Sedangkan perbuatan Badan/pejabat TUN lainnya baik perbuatan materiil (material daad) maupun penerbitan peraturan (regeling) masing-masing merupakan kewenangan peradilan umum dan Mahkamah Agung Kompetensi Absolut pengadilan TUN diatur dalam pasal 1 angka 10 UndangUndang Nomor 51 Tahun 2009 tentang perubahan kedua Undang-Undang Nomor 5 Tahun 1986 tentang Peradilan Tata Usaha Negara, yang menyebutkan :

"Sengketa Tata Usaha Negara adalah sengketa yang timbul dalam bidang Tata Usaha Negara antara orang atau Badan Hukum Perdata dengan badan atau pejabat tata usaha Negara, baik dipusat maupun didaerah, sebagai akibat dikeluarkannya keputusan tata usaha Negara, termasuk sengketa kepegawaianberdasarkan peraturan perundang-undangan yang berlaku."

Sedangkan yang dimaksud dengan Keputusan Tata Usaha Negara menurut ketentuan Pasal 1 angka 9 UndangUndang Nomor 9 Tahun 2009 tentang 
perubahan kedua Undang-Undang Nomor 5 Tahun 1986 tentang Peradilan Tata Usaha Negara adalah suatu penetapan tertulis yang dikeluarkan oleh Badan/Pejabat TUN yang berisi tindakan hukum TUN berdasarkan peraturan perundang-undangan yang berlaku, yang bersifat kongkrit, individual dan final sehingga menimbulkan akibat hukum bagi seseorang atau badan hukum perdata. Dari rumusan pasal tersebut, persyaaratan keputusan tun yang dapat menjadi objek persyaratan keputusan TUN yang dapatmenjadi obyek dipengadilan TUN meliputi :

1) Penetapan tertulis

2) Dikeluarkan oleh Badan/Pejabat TUN

3) Berisi tindakan hukum TUN

4) Berdasarkan peraturan perundangundangan yang berlaku

5) Bersifat konkrit, individual dan final

6) Menimbulkan akibat hukum bagi seseorang atau badan hukum perdata.

Keenam persyaratan tersebut bersifat kumulatif, artinya untuk dapat dijadikan obyek sengketa di Peradilan TUN, keputusan TUN harus memenuhi keenam persyaratan tersebut. Selain itu kompetensi peradilan TUN termasuk juga ketentuan yang terdapat dalam pasal 3 Undang-Undang Nomor 51 Tahun 2009 tentang Peradilan Tata Usaha Negara yaitu, dalah hal Badan/Pejabat TUN tidak mengeluarkan suatu keputusan yang dimohonkan kepadanya sedangkan hal itu merrupakan kewajibannya.

Ketetapan atau keputusan TUN menurut doktrin dibedakan atas dua, yaitu ketetapan (Keputusan) positif dan ketetapan negative.Ketetapan positif menimbulkan hak dan kewajiban bagi yang dikenai ketatapan, sedangkan ketetapan negative adalah berbentuk pernyataan tidak berkuasa (onbevoegdverklaring) pernyataan tidak diterima, atau suatu penolakan (afwijzing) ${ }^{12}$.Kemudian dalam perkembangannya dikenal pula istilah keputusan fiktif negative, yaitu suatu keputusan fiktif pejabat TUN yang ditandai dengan pejabat TUN yang sengaja tidak mengeluarkan suatu keputusan, yang seharusnya menjadi kewenangannya padahal seluruh syarat yang dibutuhkan tidak dipenuhi oleh pihak yang seharusnya diberikan KTUN.

Dalam pasal 3 Undang-Undang Nomor 5 Tahun 1986 tentang Peradilan Tata Usaha Negara disebutkan :

a. Apabila Badan atau Pejabat Tata Usaha Negara tidak mengeluarkan keputusan, sedangkan hal itu menjadi kewajibannya, maka hal tersebut disamakan dengan Keputusan Tata Usaha Negara.

b. Jika suatu Badan/Pejabat Tata Usaha Negara tidak mengeluarkan keputusan yang dimoho, sedangkan jangka waktu sebagaiman ditentukan data peraturan perundanga-undangan yang dimaksud telah lewat, makaBadan/Pejabat Tata Usaha Negara tersebut dianggap telah menolak mengeluarkan keputusan yang dimaksud.

c. Dalam hal peraturan perundangundangan yang bersangkutan tidak menentukan jangka waktu sebagaimana dimaksud dalam ayat (2), maka setelah lewat jangka waktu empat bulan sejak diterimanya permohonan, Badan/Pejabat Tata Usaha Negara yang bersangkutan dianggap telah mengeluarkan keputusan penolakan.

Dalam praktek Keputusan Badan/Pejabat TUN yang berpotensi menimbulkan sengketa TUN, yaitu antara lain :

a) Keputusan tentang perjanjian

b) Keputusan tentang status hukum, hak dan kewajiban

12 W. Riawan Tjandra, Tori dan Praktik Peradilan Tata Usaha Negara, (Yogyakarta ; Universitas Atmaa Jaya, 2014), h.26 
c) Keputusan tentang kepegawaian Akan tetapi kompetensi Peradilan Tata Usaha Negara sebagaiman disebutkan dalam pasal 1 angka 9 Undang-Undang Nomor 51 Tahun 2009 tentang perubahan kedua atas UndangUndang Nomor 5 Tahun 1986 tentang Peradilan Tata Usaha Negara dibatasi oleh ketentuan pasal 2, pasal 48, pasal 49, dan pasal 142 Undang-Undang Peradilan tersebut, sehingga pembatasan terhadap obyek sengketa pengadilan Tata Usaha Negara tersebut dibedakan menjadi : pembatasan langsung, pembatasan tidak langsung dan pembatasan langsung bersifat sementara.

a) Pembatasan Langsung merupakan pembatasan yan tidak memungkinkan sama sekali bagi Peradilan Tata Usaha Negara untuk memeriksa,memutus, dan mengadil sengketa tersebut. Hal ini disebutkan secara tegas dalam peraturan Tata Usaha Negara dalam pasal 2, pasal 49 Undang-Undang Nomor 51 Tahun 2009 tentang perubahan kedua atas UndangUndang Nomor 5 Tahun 1986 tentang Peradilan Tata Usaha.

b) Pembatasan Tidak Lnagsung adalah pembatasan yang masih membuka kemungkinan bagi Peradilan Tata Usaha Negara untuk memeriksa, memutus dan menyelesaikan sengketa administrasi dengan ketentuan seluruh upaya administratif yang tersedia telah ditujukan terlebih dahulu oleh Orang/Badan hukum perdata. Pembatasan tidak langsung tersebut terdapat dalam pasal 48, dan ditegaskan dalam pasal 51 ayat (3) Undang-Undang Nomor 51 Tahun 2009 tentang perubahan kedua atas Undang-Undang Nomor 5 Tahun 1986 tentang Peradilan Tata Usaha.

c) Pembatasn Langsung yang Bersifat Sementara

Pembatasan ini bersifat langsung karena tidak terbuka kemungkinan bagi peratun untuk memerika, memutus dan menyelesaikan, akan tetapi hal tersebut hanya bersifat sementara karena kompetensi absolut peradilan TUN tersebut berlaku bagi sengketa Tata Usaha Negara yang sedang diadili oleh Peradilan Umum pada saat terbentuknya peradilan TUN, sebagaimana disebutkan dalam pasal 142 ayat (1) Undang-Undang Nomor 51 Tahun 2009 tentang perubahan kedua atas Undang-Undang Nomor 5 Tahun 1986 tentang Peradilan Tata Usaha.

Dalam perkembangan Peradilan Tata Usaha Negara, kompetensi absolut peradilan TUN tersebut dibatasi pula oleh lahirnya peraturan perundang-undangan yang baru serta Yurisprudensio Mahkamah Agung Republik Indonesia, yaitu antara lain:

Pembatasan karena lahirnya

Peraturan Perundang-undangan yang baru,

Pembatasan karena yurisprudensi MA RI misalnya, tentang risalah lelang, sengketa kepemilikan tanah, Keputusan TUN yang diterbitkan dalam rangka untuk menimbulkan perjanjian, akta jual beli yang dibuat oleh PPAT, Keputusan yang merupakan perbuatan hukum dalam ruang lingkup politik, keputusan rector perguruan tinggi swasta.

\section{Persamaan dan Perbedaan Prosedural Peradilan Umum (Perdata) dengan Peradilan Tata Usaha Negara}

Adanya kalangan yang menyamakan Peradilan Umum (Perdata) dengan Peradilan Tata usaha Negara, pendapat tersebut menyamakan begitu saja kedua peradilan ini adalah suatu kesalahan. Adapun kesamaan antara kedua Peradilan tersebut antara lain sebagai berikut :

\section{Pengajuan Gugatan}

Pengajuan gugatan terhadap Peradilan Umum termuat dalam pasal 118 HIR (Herzien Indonesis Reglement) sedangkan dalam Peradilan Tata Usaha Negara termuat dalam Pasal 54 UndangUndang Nomor 51 Tahun 2009 tentang 
perubahan kedua atas Undang-Undang Nomor 5 Tahun 1986 tentang Peradilan Tata Usaha. Berdasarkan pasal-pasal tersebut, keduanya menganut asas bahwa gugatan diajukan kepengadilan yang daerah hukumnya meliputi kedudukan atau tempat tinggal tergugat.

\section{Isi Gugatan}

Persyaratan mengenai isi gugatan dalam peradilan umum (perdata) termuat dalam Pasal 8 Nomor 3 Rv (Reglement op de Burgerlijke Rechtsvordering), sedangkan dalam Peradilan Tata Usaha Negara termuat dalam Pasal 56 UndangUndang Nomor 51 Tahun 2009 tentang perubahan kedua atas Undang-Undang Nomor 5 Tahun 1986 tentang Peradilan Tata Usaha. Berdasarkan pasal tersebut, persyaratan mengenai isi gugatan pokoknya memuat ; identitas para pihak (penggugat dan tergugat), fundamentum petendi atau posita (alasan gugatan), Petitum (harapan penggugat atas gugatan yang diajukan).

\section{Pendaftaran Perkara}

Dalam Peradilan Umum (Perdata) pendaftaran perkara termuat dalam 121 HIR (Herzien Indonesis Reglement) sedangkan dalam Peradilan Tata Usaha Negara termuat dalam pasal 59 UndangUndang Nomor 51 Tahun 2009 tentang perubahan kedua atas Undang-Undang Nomor 5 Tahun 1986 tentang Peradilan Tata Usaha. Berdasarkan pasal diatas, maka gugatan diajukan kepengadilan yang berwenang baik secara kompetensi absolut maupun relatif.

\section{Penetapan Hari Sidang \\ Menurut peradilan umum (Perdata)} terkait penetapan hari siding termuat dalam pasal 122 HIR (Herzien Indonesis Reglement) sedangkan dalam Peradilan Tata Usaha Negara terdapat dalam Pasal 64 Undang-Undang Nomor 51 Tahun 2009 tentang perubahan kedua atas UndangUndang Nomor 5 Tahun 1986 tentang Peradilan Tata Usaha. Berdasarkan pasal tersebut, maka setelah surat gugatan didaftarkan dalam buku daftar perkara dan telah dianggap cukup lengkap, pengadilan menentukan hari dan jam sidang di pengadilan. Dalam menentukan hari siding, hakim harus mempertimbangkan jarak antara tempat tinggal para pihak yang beperkara dengan pengadilan tempat persidangan.

5. Pemanggilan para pihak

Dalam Peradilan Umum (Perdata) termuat dalam Pasal 390 ayat (1) dan Pasal 126 HIR (Herzien Indonesis Reglement), sedangkan dalam Peradilan Tata Usah Negara termuat dalam Pasal 65 dan 66 Undang-Undang Nomor 51 Tahun 2009 tentang perubahan kedua atas Undang-Undang Nomor 5 Tahun 1986 tentang Peradilan Tata Usaha.

\section{Pemberian Kuasa}

terkait pemberian kuasa, dalam Peradilan Umum (Perdata) termuat dalam Pasal 123 ayat (1) HIR (Herzien Indonesis Reglement), sedangkan dalam Peradilan Tata Usah Negara termuat dalam Pasal 57 Undang-Undang Nomor 51 Tahun 2009 tentang perubahan kedua atas UndangUndang Nomor 5 Tahun 1986 tentang Peradilan Tata Usaha. Apabila dikehendaki, para pihak dapat diwakili atau didampingi oleh seorang atau beberapa orang kuasa.Pemberian kuasa ini dapat dilakukan sebelum atau selama perkara diperiksa.

\section{Persidangan Terbuka Untuk Umum}

Sidang pemeriksaan perkara dipengadilan pada dasarnya terbuka untuk umum, dengan demikian setiap orang dapat hadir mendengarkan jalannya pemeriksaan perkara tersebut. Dalam Peradilan Umum (Perdata) termuat dalam Pasal 179 ayat (1) HIR (Herzien Indonesis Reglement), sedangkan dalam Peradilan Tata Usah Negara termuat dalam Pasal 70 ayat (1) Undang-Undang Nomor 51 Tahun 2009 tentang perubahan kedua atas Undang-Undang Nomor 5 Tahun 1986 tentang Peradilan Tata Usaha. 
8. Pencabutan dan Perubahan gugatan

Penggugat dapat sewaktu-waktu mencabut gugatannya sebelum tergugat memberikan jawabannya, jika tergugat sudah memberikan jawabannya, maka akan dikabulkan oleh hakim, apabila mendapat persetujuan hakim, sebagaiman termuat dalam Pasal $271 \mathrm{Rv}$ (Reglement op de Burgerlijke Rechtsvordering), dan Pasal 76 Undang-Undang Nomor 51 Tahun 2009 tentang perubahan kedua atas Undang-Undang Nomor 5 Tahun 1986 tentang Peradilan Tata Usaha.

\section{Hak Ingkar}

Guna menjaga obyektifitas dan keadilan dari putusan peradilan, maka hakim, panitera wajib mengundurkan diri, apabila terdapat hubungan darah atau hubungan suami istri atau meskipun telah bercerai dengan salah satu pihak yang beperkara, sebagaimana termuat dalam Pasal 374 ayat (1) HIR (Herzien Indonesis Reglement), serta dalam pasal 78 dan 79 Undang-Undang Nomor 51 Tahun 2009 tentang perubahan kedua atas UndangUndang Nomor 5 Tahun 1986 tentang Peradilan Tata Usaha.

\section{Pembuktian}

Baik Peradilan Umum (Perdata0 ataupun Peradilan Tata Usaha Negara, menganut asas bhawa beban pembuktian ada pada kedua belah pihak sebagimana termaktum dalam Pasal 163 dan 164 HIR (Herzien Indonesis Reglement), serta dalam Pasal 100 sampai dengan 107 Undang-Undang Nomor 51 Tahun 2009 tentang perubahan kedua atas UndangUndang Nomor 5 Tahun 1986 tentang Peradilan Tata Usaha.

11. Pelaksanaan Putusan Pengadilan
Pelaksanaan putusan dilakukan
setelah memperoleh putusan yang
memiliki kekuatan hukum tetap
sebagaimana dalam Pasal 195 HIR
(Herzien Indonesis Reglement), serta dalam Pasal 115 dan 116 Undang-Undang Nomor 51 Tahun 2009 tentang perubahan kedua atas Undang-Undang Nomor 5
Tahun 1986 tentang Peradilan Tata Usaha. ${ }^{13}$

Selain persamaan diatas, terdapat pula perbedaan antara Peradilan Umum (Perdata) dengan Peradilan Tata Usaha Negara, antara lain:

\section{Obyek Gugatan}

Obyek gugatan dalam Peradilan Umum (Perdata) adalah Perbuatan melawan hukum (onrechtmatigdaad) sedangkan dalam Peradilan Tata Usaha Negara obyek gugatannya adalah Keputusan TUN yang dikeluarkan oleh Badan/Pejabat TUN (onrectsmatig overheid daad).

\section{Kedudukan Para Pihak}

Kedudukan para pihak dalam sengketa TUN selalu menempatkan seseorang atau badan hukum perdata sebagai pihak penggugat dan badan atau pejabat TUN sebagai pihak tergugat, sedangkan dalam hukum acara perdata tidaklah demikian itu, dapat saja para pihak sesame individu, sesame badan hukum perdata, atau antara individu dengan suatu badan hukum perdata, dan lain-lain.

\section{Gugat Rekonvensi}

Dalam Peradilan Umum (Perdata) dikenal istilah gugat rekonvensi.Rekonvensi (gugat balik) adalah gugatan yang diajukan oleh tergugat terhadap penggugat dalam sengketa yang sedang berjalan antara mereka. ${ }^{14}$ Sedangkan PTUN tidak mengenal adanya gugat rekonvensi karena dalam gugatan rekonvensi berarti kedudukan para pihak semula menjadi berbalik, padahal dalam PTUN kedudukan

13Zairin Harahap, Hukum Acara Peradilan Tata Usaha Negara, (Jakarta: Raja Grafindo Persada, 2003), h. 37-39

${ }^{14}$ Soedikno Mertokoesomo, Hukum Acara Perdata Indonesia, (Cetakan Pertama, Edisi Kedua, 1985), h. 96 
para pihak sudah definitf, tidak dapat berubah.

4. Tenggang Waktu Pengajuan Gugatan

Dalam pengajuan gugatan TUN, tenggang waktu 90 hari dihitung sejak diterimanya keputusan TUN. Sedangkan dalam Peradilan Umum (Perdata) lebih lama dalam pengajuan gugatannya karena adanya gugatan prematur dalam prosedural pengajuan gugatan dapat saja terjadi

\section{Tuntutan Dalam Gugatan}

Dalam Peradilan Umum (Perdata) boleh dikatakan bahwa tuntutan pokok itu (petitum primair) disertai dengan tuntutan penganti (petitum subsidier), sedangkan dalam Peradiln Tata Usaha Negara, hanya dikenal satu macam tuntutan pokok yang berupa tuntutan agar Keputusan TUN yang digugat itu dinyatakan batal Atau tidak sah atau dalam tuntutatan agar Keputusan TUN yang dimohonkan oleh penggugat dikeluarkan oleh tergugat.

\section{Putusan Verstek}

Kata Verstek berarti pernyataan bahwa tidak datang pada hari siding pertama.Dalam Peradilan Umum (Perdata) putusan verstek dijatuhakan pada siding pertama, apabila tergugat tidak datang setelah dipanggil dengan patut.Sedangkan dalam Peradilan TUN, berdasarkan Pasal 72 ayat (1) Peradilan TUN, maka dapat diketahui bahwa Peradilan TUN tidak mengenal putusan verstek.Alasan tidak dikenalnya putusan verstek ini menurut Wicipto Setiadi adalah karena badanatau pejabat TUN yang digugat tidak mungkin tidak diketahui kedudukannya. ${ }^{15}$

\section{Titik Singgung Kompetensi Peradilan Umum (Perdata) dengan Peradilan Tata Usaha Negara}

15Wicipto Setiadi, Hukum Acara Pengadilan Tata Usaha Negara Suatu Perbandingan, (Jakarta: Raja Grafindo Persada, 1994), h.177
Persinggungan kewenangan antara Peradilan Umum (perdata) dengan Peradilan Tata Usaha Negara (TUN) sangat mungkin terjadi dalam hal perbuatan melawan hukum oleh penguasa (onrechtmtigedaad van ambtsdrager). ${ }^{16}$ Persinggungan ini dikarenakan sifat dari perbuatan melawan hukum oleh penguasa bersegi dua, yaitu dapat bersegi melawan, hukum berdasar suatu hubungan hukum keperdataan atau berdasarkan suatu hubungan hukum publik.

Ada perbedaan sistem peradilan administratif di Indonesia dengan Belanda.Di Belanda sendiri, tidak terdapat peradilan administratif ssebagai suatu lingkungan peradilan yang berdiri sendiri (dan oleh karenanya memiliki kewenangan atributatifnya sendiri) sebagaimana halnya di Indonesia.Keranya, upaya banding administratif di Belanda seperti pada Afdeling Rechtspraak Raad van State diperlakukan sebagai upaya hukum yang bersifat khusus (bijzondere rechtsgang).Oleh karena upaya banding administratif sebagai bijzondere rechtsgang maka peradilan Umum tidak berwenang mengadili upaya hukum tersebut dikarenakantelah ada upaya hukum untuk suatu perbuatan melanggar hukum oleh peguasa.Sementara itu di Indonesia, keberaaan Peradilan Tata Usaha Negara bukan merupakan bijzondere rechtsgang. ${ }^{17}$ Peradilan Tata Usaha Negara suatu lingkungan badan peradilan tersendiri dibawah Mahkamah Agung dan oleh undang-undang diatribusi kewenangan sesuai dengan fungsinya sebagai pengadilan administrasi.

Baik upaya hukum khusus (bijzondere rechtsgang) seperti di Belanda maupun peradilan administrasi di Indonesia

\footnotetext{
${ }^{16}$ Sudikno Mertokusumo, Perbuatan Melawan Hukum oleh Pemerintah, (Yogyakarta: Cahaya Atma Pustaka, 2014), h. 9

17 Setiawan, Aneka Masalah HUkum dan Hukum Acara Perdata,(Bandung: Alumni, 1992), h. 351-352.
} 
bertujuan untuk memberikan perlindungan hukum (rechtsbesheriming) kepada warga masyarakat (citizen). Atas dasar maksud itulah maka Peradilan Umum (perdata) wajib menyatakan dirinya tidak berwenang untuk mengadili perkara jika:

a. Undang-undang telah menentukan adanya badan pengadilan administrasi yang bertugas mengadili sengketa tertentu atau pun telah terbukanya kemungkinan untuk suatu banding administratif;

b. Apabila upaya khusus (bijzondere rechtsgang) tadi disertai dengan jaminan yang cukup akan proses peradilan yang tidak berpihak (impartial). ${ }^{18}$

Permasalahan titik singgung kewenangan Peradilan Umum dan Peradilan TUN tampaknya tidak sesederhana deskripsi tersebut di atas.Ini dikarenakan perbuatan hukum penguasa hampir selalu merambah berbagai segi hukum, khususnya privat dan publik. Karena seperti kita ketahui instansi pemerintahan selain sebagai institusi publil pada keadaan tertentu ia seperti menjalani peran sebagai badan privat. Dimensi inilah yang menyebabkan penafsiran perbuatan melawan hukum penguasa sering kali sulti dibedakan apaka perbuatan itu dalam konteks hubungan keperdataan atau dalam konteks hubungan hukum publil.Sering kali ditemui gugatn terhadap perbuatan melawan hukum penguasa tetap diajukan ke Peradilan Umum karena menganggap perbuatan penguaa tersebut dalam kaitannya dengan hubungn hukum keperdataan, bukan hubungan hukum publik. ${ }^{19}$

Seperti dalam gugatan yang diajukan oleh Oen Kok Pwee (Penggugat) melawan Kepala Kantor BPN Tulungagung (Tergugat), Kepala Kantor Lelang Tulung

${ }^{18}$ Ibid, h. 352-353

${ }^{19}$ M. Natsir Asnawi, Op.cit, h. 78
Agung (Turut Tergugat), Deutsche Bank AG (Turut Tergugat), dan Pujo Basuki (Turut Tergugat), dan intervenient Lidi Ernawati. Penggugat dalam gugatanya mendalikan bahwa kepala kantor BPN Tulungagug tidak melaksanakan kewajiban yang dibebankan kepadanya oleh undang-undang yaitu menyelesaikan pelaksanaan roya dan balik naa permohonan Penggugat setelah menyerakhkan sertifikat HGB No. 20 meski Penggugat telah berkali-kali memohon ditindaklanjuti pelaksanaan roya dan balik nama tersebut.

Pengadilan Negeri Tulungagung dalam putusan Nomor 37/Pdt.G/1996/PN.Ta tanggal 15 April 1997 menyatakan bahwa Pengadilan Negeri Tulung Agung tidak berwenang mengadili perkara tersebut. Kemudian pada tingkat banding Pengadilan Tinggi Surabaya dalam putusan Nomor 676/Pdt/1997/PT.Sby tanggal 12 Maret 1998 membatalkan putusan PN Tulungagung dan memerintahkan PN Tulungagung memeriksa kembali pokok perkara. Putusan terakhir kemudian dibatalkan pada tingkat kasasi melalui putusan Mahkamah Agung Nomor 620 K/Pdt/1999 tanggal 29 Desember 1999.

Dalam pertimbangannya Mahkamah Agung berpendapat:

"bahwa gugatan Penggugat asal pada pokoknya ditujukan kepada Kepala Badan atau Pejabat Tata Usaha Negara, sedangkan objek gugatan menyangkut perbuatan yang menjadi wewenang Pejabat tersebut, sehingga dengan demikian kewenangan untuk mengadili perkara tersebut bukn merupakan kewenangan Pengadilan Negeri melainkan kewenangan Pengadilan Tata Usaha Negara".

Pada kasus tersebut, tampak Penggugat asal menganggap perbuatan Kepala BPN yang tidak meroya dan membalik nama sertifikat HGB yang diajukan Pengguagat sebagai perbuatan melawan hukum penguasa dalam 
hubungan keperdataan. Anggapan ini jamak di masyarakat yang mungkin juga masih belum benar-benar dapat membedakan perbuatan penguasa dari sisi hubungan keperdataan dan hubungan publik. Dengan putusan tersebut, maka menjadi jelas demarkasi kewenangan Peradilan Umu dan Peradilan Tata Usaha Negara dalam perbuatan melawan hukum penguasa, yaitu sepanjang perbuatan tersebut benar-benar merupakan perbuatan yang menjadi kewenangan atibutif perjabat TUN maka menjadi kewenangan Peradilan TUN.

Guna mengatasi persepsi yang berbeda mengenai kewenangan mengadilli antara Peradilan Umum dengan Peradilan Tata Usaha Negara, Mahkamah Agung pada tahun 2012 telah acara merumuskan beberapa hal sebagai pemecahan atas masalah hukum acara yang dihadapi selama ini. Khusus mengenai titik singgung kewenangan Peradian Umum dengan Peradilan TUN, telah dirumuskan beberapa kaidah hukum yang dapat dijadika pedoman dalam mengatasi persinggungan kewenangan antara peradilan Umum dengan Peradilan TUN sebagai berikut ${ }^{20}$.

1. Kriteria sengketa TUN dan Perdata Permasalahan titik singgung kewenangan antara peradilan Umum (PU) dengan Peradilan TUN (PTUN) adalah kesulitan dalam menetapkan apakah suatu sengketa termassuk sengketa TUN atau perdata.Seperti diuraikan sebelumnya, perbuatan hukum (rechtshandeling) penguasa (pejabat TUN) memiliki beberapa segi, terutama segi hubungan keperdataan dan segi hubungan hukum public. Terhadapa hal itu, Kamar Tata Usaha Negara dalam rapat plenonya merumuskan beberapa kriteria dalam menentukan apakah suatu sengketa

${ }^{20}$ Lihat Mahkamag Agung, Rumusan Hukum Hasil Rapat Pleno Kamar Makmah Agung Republik Indonesia,(Jakarta: Mahkamah Agung RI, 2012), h. 1-2 termasuk sengketa TUN atau sengketa perdata sebagai berikut:

a) Apabila yang menjadi objek sengketa (objectum litis) tentang keabsahan Keputusan TUN, maka merupakan sengketa TUN;

b) Apabila dalam posita gugatan mempermasalahkan kewenangan, keabsahan Prosedur penerbitn KTUN, maka termasuk sengketa TUN;

c) Apabila satu-satunya penentu apakah Hakim dapat menguji kabsahan Keputusan TUN, objek sengketa adalah subtansi hak karena tentang hal tersebut menjadi kewenangan peradilan perdata;

d) Apabila norma (kaidah) hukum TUN (hukum publik) dapat menyelasikan sengketanya, maka dapat digolongkan sebagai sengketa TUN

\section{Ollosing theory (teori melebur)}

Beberapa tindakan hukum (keputusan TUN) dari pejabat TUN dianggap bukan lagi tindakan administratif semata.Pada keadaan tertentu, tundakan pejabat TUN dapat melebut menjadi tindakan dalam hubungan keperdataan.Terkait hal ini, dikenal istilah opplosing theory sebagai pedoman dalam menilai apakah tindakan hukum pejabat TUN melebur tau tidak sebgai tindakan dalam hubungan keperdataan. Untuk memastikan suatu Keputusan TUN dianggap melebur dalam perbuatan hukum perdata adalah apabila seccra faktual Keputusan TUN yang disengketakan dan diminta diuji keabsahanya ternyata:

a) Jangkauan akhir dari Keputusan TUN diterbitkan (tujuannya) dimaksudkan untuk melahirkan suatu perbuatan hukum perdata. Termasuk didalamya adalah Keputusan-keputusan TUN yang diterbitkan dalam rangka mempersiapkan atau menyelesaikan suatu perbuatan hukum perdata; 
b) Apabila Tergugat dalam menerbitkan Keputusan TUN objek sengketa akan menjadi subjek atau pihak dalam perikatan perdata sebagai kelanjutan Keputusan TUN objek sengketa tersebut;. ${ }^{21}$

KTUN yang berkaitan dengan ijin cerai tidak digolongkan sebagai Keputusan TUN yang melebur dalam ijin cerai merupakan ketentuan hukum public (hukum administrasi) sebagai syarat bagi PNS yang akan melakukan perceraian. Dengan demikian ijin cerai merupakan lexspesialis (kekuatan khusus) dan dikeculikan dari penerapan teori melebur.

\section{Kesimpulan}

Titik Singgung Kompetensi Peradilan Umum (Perdata) dan Peradilan Tata Usaha Negara secara Absolut lebih menekankan terhadap obyek sengketa, posita sengketa serta norma (kaidah) hukum yang mampu memenuhi proses peradilan. Untuk itu, perlu kiranya kejelihan hakim dalam melihat alasanalasan pengajuan gugatan, sehingga proses peradilan yang berlangsung akan semakin mudah karena sudah ditentukan dari awal apakan kompetensi dalam gugatan yang diajukan tersebut masuk ranah Peradilan Umum (Perdata) ataukan masuk ranah Peradilan Tata Usaha Negara. Jikalau melihat dalam prosedur Peradilan Tata Usaha Negara adanya rapat permusyawaratan yang dilakukan oleh para majelis hakim, yang merupakan prosedural penyelesaian sengketa perkara yang disederhanakan (vereen voudigde behandeling atau dismissal procedure) dimana prosedural yang dimaksud guna memutus suatu sengketa dengan pertimbangan-pertimbangan bahwa gugatan yang diajukan oleh penggugat tidak diterima dengan alasan karena bukanlah kewenangan peradilan Tata

${ }^{21}$ Keadaan pada huruf (a) dan (B) tersebut menyebabkan KTUN melebur menjadi perbuatan perdata karenanya menjadi kewenangan dari Peradian Umum
Usaha Negara, atau alasan-alasan gugatan yang disertakan tidak layak atau bahkan apa yang dituntut dalam gugatan sebenarnya sudah terpenuhi dalam Keputusan Tata Usaha Negara sehingga dinilai cacat hukum jika proses gugatan tersebut dilanjutkan.

Hal ini menjadi langkah positif jika dimaksimalkan dengan sebaiknya, guna pemenuhan hak dari penggugat.Dalam hal ini, hakim memberikan kepastian hukum sedini mungkin kepada penggugat asalkan keputusan yang dihasilkan melalui pertimbangan hukum yang valid dari majelis hakim, sehingga sedini mungkin penggugat bisa mendapatkan kepastian hukum dari peradilan yang diinginkan.

\section{Daftar Pustaka}

Departemen Pendidikan Nasional Direktorat Jenderal Pendidikan Dasar Dan Menengah,Dasar-Dasar Bimbingan Dan Konseling, 2003.

Edi Purwanto,Modifikasi Prilaku, Yogyakarta: Pustaka Pelajar Offset, 2012.

Enjang AS,Komunikasi Konseling,Bandung : Nuansa, 2009.

Erhamwilda, Konseling Islami,Yogyakarta: Graha Ilmu, 2009.

Latipun,Psikologi Konseling,Malang : UMM Press, 2005.

Masnah, "Pengaruh Bimbingan Kelompok Terhadap Asertivitas Pada Siswa Kelas XI Ma Islahun Ikhwan Nw Mispalah Praya Tengah Tahun Pelajaran 2013/2014". Skripsi, Mataram : Fakultas Ilmu Pendidikan Institut Keguruan dan Ilmu Pendidikan, 2014.

Pengurus Besar Asosiasi Bimbingan dan Konseling Indonesia,Kode Etik Profesi Bimbingan dan Konseling Indonesia, 2010.

Pujiarohman, "Pengaruh Program Peningkatan Perilaku Asertif Untuk 
Menolak Hubungan Seks Pranikah Bagi Remaja Dengan Melibatkan Orangtua",Tesis, Yogyakarta: Fakultas Psikologi Universitas Gadjah Mada, 2011

Rakos, R. F.,Assertive Behavior: Theory, Research, and Training. London and New York: Routledge, 1991.

Syamsu Yusuf \& Nurihsan Juntik,Landasan Bimbingan dan Konseling. Bandung : Rosdakarya, 2005. 